\title{
Integrating the anaerobic process with ultrafiltration in meat industry wastewater treatment ${ }^{1}$
}

\section{Zintegrowanie beztlenowego procesu z ultrafiltracją w oczyszczaniu ścieków z przemysłu mięsnego}

\begin{abstract}
* Dr inż. Anna Kwarciak-Kozłowska, mgr inż. Aleksandra Krzywicka, mgr Lucyna Sławik-Dembiczak, Faculty of Environmental Engineering and Biotechnology, Institute of Environmental Protection, Czestochowa University of Technology, Brzeźnicka 60A St., 42-200 Czestochowa, Poland, e-mail: akwarciak@is.pcz.czest.pl, aleksandra.krzyw@gmail.com, Islawik@is.pcz.czest.pl
\end{abstract}

Keywords: anaerobic process, ASBR reactor, ultrafiltration, meat industry wastewater, biogas, anaerobic granular sludge Słowa kluczowe: proces beztlenowy, reaktor ASBR, ultrafiltracja, ścieki z przemysłu mięsnego, biogaz, beztlenowy osad granulowany

\section{Abstract}

The aim of this paper was to study meat industry wastewater treatment efficiency during fermentation process in ASBR reactor and post-treatment in UF process. The anaerobic process obtained a considerable degree of the removal of organic pollutants from raw wastewater designated as COD $(73.3 \%)$, BOD $(71.4 \%)$ and TOC $(83.2 \%)$. The concentrations of COD and BOD were 435 and $443 \mathrm{mg} / \mathrm{dm}^{3}$, respectively. The value of TOC reached a level of $136 \mathrm{mg} / \mathrm{dm}^{3}$. Generated biogas in the methane fermentation process of wastewater from meat industry plants was characterized by high methane content $(80.9 \%$ vol.). In the final part of the experiment, the UF process was used in order to posttreating effluent from ASBR reactor. During the UF process, COD BOD and TOC parameters were removed at $67.2 \%, 68 \%$ and $70.4 \%$, respectively.

(C) IOŚ-PIB

\section{INTRODUCTION}

The Polish meat industry started to grow rapidly in 2004. EU subsidies allowed numerous meat processing plants to make multimillion investments, which, in turn, led to increased production and helped raise the quality of products [Gudelis-Matys 2004, Konieczny 2007]. The high consumption of premium quality water and plants' limited ability to recycle such water is the result of strict health and quality-related requirements. Consequently, plants that use huge amounts of water inevitably generate large amounts of condensed industrial wastewater, with varying physical and chemical composition. Several dozen cubic metres of such industrial wastewater contain a fraction of pollution contained in municipal wastewater generated by a town of several dozen thousands inhabitants. According to the Central Statistical Office annual publication, 13.1 million cubic tons of this kind of industrial wastewater is generated during production and processing of meat [GudelisMatys 2004, Konieczny, Szymański2007, Bartkiewicz 2007].

Meat industry wastewater is a potential source of epidemiological threats, mainly due to massive amounts of blood and stomach contents of slaughtered animals. Such wastewater has high

\section{Streszczenie}

Celem pracy było zbadanie skuteczności oczyszczania ścieków z branży mięsnej w procesie fermentacji metanowej prowadzonej w reaktorze ASBR a następnie ich doczyszczanie w procesie ultrafiltracji. Proces beztlenowy przyczynił się w znacznym stopniu do usunięcia z badanych ścieków zanieczyszczeń organicznych oznaczanych jako ChZT(73,3\%), BZT5 $(71,4 \%)$ i OWO $(83,2 \%)$. Stężenia ChZT i BZT $\mathrm{B}_{5}$ w ściekach oczyszczonych beztlenowo wynosiły odpowiednio $435 \mathrm{mg} / \mathrm{dm}^{3}$ i $443 \mathrm{mg} / \mathrm{dm}^{3}$. Wartość OWO obniżyła się do poziomu $136 \mathrm{mg} / \mathrm{dm}^{3}$. Generowany w procesie beztlenowym biogaz charakteryzował się wysoką zawartością metanu ( $80,9 \%$ obj.). W ostatnim etapie badań w celu doczyszczenia odcieku z reaktor ASBR skierowano go na modułu ultrafiltracyjny. Proces ultrafiltracji pozwolił na usunięcie ChZT, BZT ${ }_{5}$, OWO odpowiednio o $67,2 \%, 68 \%$ i $70,4 \%$. biological and chemical demand for oxygen, contains a lot of fat, dry matter (50\% of which is organic matter), suspensions and biogenic compounds. This kind of wastewater is easily putrescible and generate foul odour due to the presence of protein substances. Meat processing wastewater is difficult to treat due to large amounts of pollutants and their character and also due to uneven, cyclical generation [Chavez et al. 2005, Bartkiewicz 2007, Del Neryet al. 2001, Nardiet al. 2001].

Sequence batch reactors are an attractive alternative to conventional systems. These may be aerobic systems (SBR) or anaerobic systems (ASBR) [Bing et al. 2005, Neczajet al. 2008].The technology's key point is the charging process (applying batches), rather than the traditional "constant flow" approach. The sequence batch reactor operation is flexible enough to accommodate quick and easy changes to process operating parameters, depending on the amount and composition of wastewater to be treated. All stages of the treatment process take place sequentially in the same tank without the necessity of directing the waste water to other equipment. The main advantage of the 
solution is that the bioreactor is never completely emptied and part of the sludge is left in it for another cycle. This is beneficial to the growth of microorganisms that have already adapted to the proper waste water treatment process. Apart from generation of a highly efficient fermentation gas, the characteristic for anaerobic processes, the unconventional process (ASBR) brings other benefits, such as simple and efficient operating conditions, satisfactory treatment results, low investment costs, significantly smaller space consumption when compared with classic wastewater treatment facilities and the possibility of conducting the charge process [Cheong, Hansen 2008,Shao et al. 2008].

For the last few years, a lot of attention has been focused on the development of unconventional methods for wastewater treatment, such as pressure-driven membrane operations, namely ultrafiltration, which helps in removing colloids, suspended and macromolecular matter and reverse osmosis, which helps in eliminating mineral substances and low-molecular organic compounds. The ultrafiltration has an exceptional efficiency in removal of very small particles, including pathogen microbes and environmentally hazardous nutrients [Bohdziewicz, Sroka2006, Yordanov 2010].

\section{MATERIALS AND METHODS}

\subsection{Materials}

The wastewater came sampled from the meat-processing plant near Czestochowa whose activity covers the slaughtering and processing of pigs. The values of the basic and eutrophic pollution indicators were high and ranged widely during the whole production cycle. The wastewater had a brown colour and smelled bad and was also characterized by a tendency to rot and foaming. COD of raw meat industry wastewater varied from 1630 to $1670 \mathrm{mg} / \mathrm{dm}^{3}$ and BOD was average at $1520 \mathrm{mg} / \mathrm{dm}^{3}$. High concentration of ammonia nitrogen (from 490 to $500 \mathrm{mg} / \mathrm{dm}^{3}$ ) and chloride (from 750 to $790 \mathrm{mg} / \mathrm{dm}^{3}$ ) was also observed. Lipid content (ether extract) varied from 1138 to $1420 \mathrm{mg} / \mathrm{dm}^{3}$.

\subsection{Reactor ASBR and characteristics of anaerobic granular sludge}

In the experiment, an anaerobic sequencing batch reactor (ASBR) was used. The ASBR reactor has a cylindrical shape with a total volume of $12 \mathrm{dm}^{3}$. The reactor tank was made of Plexiglass. The produced biogas was collected in a calibrated glass cylinder, which was filled with acidified aqua deionized water. The anaerobic granular sludge used in the research was picked up from an anaerobic IC reactor at the wastewater treatment plant at Zywiec S.A brewery. Granules typically have a spherical form with a diameter from 2 to $5 \mathrm{~mm}$, where the value of organic matter concentration was $69.97 \mathrm{~g} / \mathrm{dm}^{3}$ and mineral compounds achieved a value of $10.96 \mathrm{~g} / \mathrm{dm}^{3}$ (total suspensions $\left.80.93 \mathrm{~g} / \mathrm{dm}^{3}\right)$.

\subsection{Ultrafiltration unit}

In the process of membrane filtration for meat industry wastewater, an apparatus with a lab-type membrane module SEPA CFNP from American company Osmonics was used. The module consisted of two steel plates between which a flat membrane was placed in a shape of a rectangular sheet with dimensions of $190 \times 140 \mathrm{~mm}$ (total surface of the membrane was $155 \mathrm{~cm}^{2}$ and the filtration area $144 \mathrm{~cm}^{2}$ ). The whole apparatus was introduced into a steel enclosure to provide the sealing arrangement. The membrane used in the pressure-driven operations was a polymer membrane (polysulphone, type PSF-16). The system operated in the cross-flow mode.

\subsection{Analysis of wastewater}

Raw meat industry wastewater, effluent from the ASBR reactor and permeate from UF process were sampled periodically for $\mathrm{pH}$ value, alkalinity, COD, BOD ammonia nitrogen, volatile fatty acids (VFA), TOC and ether extracts [ALPHA 1990]. The chemical oxidation demand (COD) was made by means of the test method on the HACH-DR 4000 spectrophotometer. Biochemical oxidation demand in 5 days (BOD) was measured with an OxiTop respirometer. The alkalinity and chloride were measured according to the standard method. The $\mathrm{pH}$ value was determined with a pH-meter Cole Parmenr. Ammonia nitrogen and VFA were determined with the distillation method on Büchi 323-Distillation Unit. The TOC was analysed using Kiper TOC 10C Analyser PX-120 (autosampler AS40-Dione). Lipid content (ether extract) was determined by two methods: direct extraction and Soxhlet extraction. The composition of the biogas was analysed using Geotechnical Instruments GA 2000. Koch method was used to determine the total number of bacteria used. The standard test for the coliform group was carried out by the multiple-tube fermentation technique [Wójcik-Szwedzińska et al. 2000].

\section{RESULTS AND DISCUSSION}

\subsection{Treatment of meat industry wastewater in ASBR reactor}

The process was carried out with organic loading rate $1.25 \mathrm{~kg}$ $\mathrm{COD} / \mathrm{m}^{3} \mathrm{~d}$, sludge loading rate $0.062 \mathrm{kgCOD} / \mathrm{kg}_{\mathrm{vss}} \mathrm{d}$ and with the concentration of anaerobic granular sludge at the level $20 \mathrm{~g} / \mathrm{dm}^{3}$. To obtain the present objective, the anaerobic granular sludge and the raw wastewater were proportioned once per $24 \mathrm{~h}$ to the cyclic bioreactor in which their detention time was $24 \mathrm{~h}$. The times of particular cycles of bioreactor operation were: tank filling $(0.5 \mathrm{~h})$, reaction phase $(22.5 \mathrm{~h})$, sedimentation phase $(0.5 \mathrm{~h})$ and wastewater drainage $(0.5 \mathrm{~h})$.

The study was conducted until the cycle repeated. COD raw wastewater amounted to $1630-1670 \mathrm{mg} / \mathrm{dm}^{3}$. The highest levels of COD removal were observed in cycles $\mathrm{V}$ and $\mathrm{VI}$. The efficiency of COD removal in $\mathrm{V}$ and $\mathrm{VI}$ cycles was $73.1 \%\left(446 \mathrm{mg} / \mathrm{dm}^{3}\right)$ and $73.3 \%\left(443 \mathrm{mg} / \mathrm{dm}^{3}\right)$, respectively. During the anaerobic process, the highest BOD removal efficiency observed in cycles IV and V was $71 \%\left(440 \mathrm{mg} / \mathrm{dm}^{3}\right)$ and $71.4 \%\left(435 \mathrm{mg} / \mathrm{dm}^{3}\right)$, respectively. Total organic carbon (TOC) is the most relevant parameter for the global determination of organic pollution of wastewater. TOC in raw wastewater was $810 \mathrm{mgC} / \mathrm{dm}^{3}$. TOC value after anaerobic process (after VI cycle) was $136 \mathrm{mgC} / \mathrm{dm}^{3}$ (83.2\%). The characteristic of pollution in meat industry wastewater is the ether extract. The use of anaerobic process also caused the removal ether extract from the wastewater. Ether extract raw wastewater was $1138 \mathrm{mg} / \mathrm{dm}^{3}$. Ether extract removal efficiency was $80.7 \%$ $\left(220 \mathrm{mg} / \mathrm{dm}^{3}\right)$. In effluent ASBR reactor, COD, BOD, TOC and ether extract value were nearly 4-fold (COD), 17 -fold (BOD), 5-fold (TOC) and almost 4-fold (ether extract) exceeded in relation to permissible standards [Regulation ...2009]. The value of ammonia nitrogen in effluent ASBR $\left(219 \mathrm{mg} / \mathrm{dm}^{3}\right)$ exceeded 22-fold in comparison to permissible standards $\left(10 \mathrm{mg} / \mathrm{dm}^{3}\right)$ [Regulation...2009]. During the experiment, the VFA/alkalinity ratio, which properly represents fermentation, was estimated. The maximum value above which the process inhibition takes place is assumed on the level of 0.3 . The highest value of VFA/alkalinity ratio is 0.28 (I cycle). In V and VI cycles, they were in constant level in the range of $0.22-0.23$.

Additional parameters monitored during the fermentation process were daily biogas production and biogas yield. Daily biogas production and biogas yield in VI cycle were $9500 \mathrm{~cm}^{3}$ and $0.45 \mathrm{dm}^{3}{ }_{\text {biogas }} / \mathrm{gCOD}_{\text {removed }}$. Generated biogas in the methane 
fermentation process of wastewater from meat industry plants was characterized by a high methane content ( $80.5 \%$ vol.). Carbon dioxide and oxygen in the analysed biogas were $17 \%$ and $1.5 \%$, respectively. The biogas was also tracers such as unwanted hydrogen sulphide (125 ppm) and carbon monoxide (62 ppm).

\subsection{Post-treatment process - ultrafiltration}

In the final part of the experiment, the UF process was used in order to post-treating effluent from ASBR reactor. This stage started with the determination of transport properties of the membranes by finding the dependence of volume deionized water flux on transmembrane pressure. Pressure range used in this study varied from 0.2 to $0.8 \mathrm{MPa}$. It was observed that in all cases, the water flux increased with increasing transmembrane pressure. The posttreatment process was carried out at transmembrane pressure equalled to $0.4 \mathrm{MPa}$ and linear flow velocity $2 \mathrm{~m} / \mathrm{s}$. Volume permeate flux during $5 \mathrm{~h}$ post-treatment in ASBR reactor decreased to the level of $0.94 \times 10^{-5} \mathrm{dm}^{3} / \mathrm{m}^{2} \mathrm{~s}$ and was $39 \%$ lower in comparison with stabilized volume water flux. Permeate flux stabilized after $3.5 \mathrm{~h}$ The relative permeability of the membrane was $64 \%$.

During post-treatment of the wastewater in UF process, high pollution removal was observed. However, over normative concentration of COD $\left(145 \mathrm{mg} / \mathrm{dm}^{3}\right)$, BOD $\left(139 \mathrm{mg} / \mathrm{dm}^{3}\right)$, TOC $\left(40.2 \mathrm{mg} / \mathrm{dm}^{3}\right)$ and ammonia nitrogen $\left(129 \mathrm{mg} / \mathrm{dm}^{3}\right)$ was noted. COD, BOD, TOC and ammonia nitrogen removal efficiency were, respectively, $67.2 \%, 68 \%, 70.4 \%$ and $41 \%$. It was observed that the removal efficiency of ether extract was $60 \%$. Ether extract after UF process was at the level of $90 \mathrm{mg} / \mathrm{dm}^{3}$. In permeate after UF process, BOD, ammonia nitrogen and ether extract value were nearly 5-fold (BOD), 9-fold (ammonia nitrogen) and almost 2-fold (ether extract) exceeding in relation to permissible standards. The value of TOC $\left(40.2 \mathrm{mg} / \mathrm{dm}^{3}\right)$ and COD (145 mg/dm $)$ in permeate exceeded slightly in comparison to permissible standards $\left(30 \mathrm{mg} / \mathrm{dm}^{3}-\right.$ TOC and $125 \mathrm{mg} / \mathrm{dm}^{3}$ - COD). Treatment efficiency of meat industry wastewater in hybrid system ASBR-UF is presented in Table 1.

The study results should be confirmed that raw wastewater was characterized by a high numbers of psychrophilic bacteria. The effluents of these bacteria were also widely mesophiles, including coliform bacteria. As a result of wastewater in the reactor, ASBR has seen a decrease in the number of mesophilic and psychrophilic bacteria by about $65.6 \%$ and $70.8 \%$, respectively. The mesophilic and psychrophilic bacteria were obtained in the case of ultrafiltration reducing the number of bacteria at $95.9 \%$ and $96.6 \%$, respectively.

To define if treated wastewater in ASBR reactor-UF process can be diverted to technological process enlarging the study of the presence of Salmonella, Escherichia coli and Enterococciare required. Before cleaning off, process installation should be cleaned by using disinfectant each time.

\section{CONCLUSIONS}

- The concentration of COD and BOD was respectively 435 and $443 \mathrm{mg} / \mathrm{dm} 3$. The value of TOC reached at a level $136 \mathrm{mg} / \mathrm{dm}^{3}$.

- During post-treatment of the wastewater in UF process, COD, BOD, TOC and ammonia nitrogen removal efficiency were, respectively, $67.2 \%, 68 \%, 70.4 \%$ and $41 \%$.

- In permeate after UF process, the concentration of COD (145 mg/dm $\left.{ }^{3}\right)$, BOD (139 mg/dm $\left.{ }^{3}\right)$, TOC $\left(40.2 \mathrm{mg} / \mathrm{dm}^{3}\right)$ and ammonia nitrogen $\left(129 \mathrm{mg} / \mathrm{dm}^{3}\right)$ was noted.

- High level removal number of bacteria was observed for the use of ultrafiltration. The mesophilic and psychrophilic bacteria were obtained in the case of ultrafiltration reducing the number of bacteria at $96.4 \%$ and $97 \%$, respectively;

- Due to poor quality, permeate from ASBR-UF hybrid system cannot be discharged into natural water.

- When the wastewater needs to be recirculated to the production cycle, an additional treatment using reverse osmosis is recommended.

\section{ACKNOWLEDGEMENTS}

The financial support from the Ministry of Science and Higher Education in Poland is greatly acknowledged. The study has been funded by BS/PB-401-301/11.

Table 1.Treatment efficiency of meat industry wastewater in hybrid system ASBR-UF

\begin{tabular}{|c|c|c|c|c|c|c|}
\hline \multirow{2}{*}{ Pollution indices } & \multirow{2}{*}{$\begin{array}{l}\text { Concentration of } \\
\text { pollution in raw } \\
\text { wastewater }\end{array}$} & \multicolumn{2}{|c|}{$\begin{array}{l}\text { Wastewater after } \\
\text { anaerobic process }\end{array}$} & \multicolumn{2}{|c|}{$\begin{array}{l}\text { Wastewater after UF } \\
\text { process (permeate) }\end{array}$} & \multirow{2}{*}{$\begin{array}{c}\text { Permissible } \\
\text { standards } \\
\text { natural receiver } \\
\text { [Regulation...2009 }\end{array}$} \\
\hline & & Concentration & $R^{2}(\%)$ & Concentration & $R^{2}(\%)$ & \\
\hline $\operatorname{COD}\left(\mathrm{mg} / \mathrm{dm}^{3}\right)$ & $1630 \pm 25.2$ & $443 \pm 24.8$ & 73.3 & $145 \pm 23.9$ & 67.2 & 125 \\
\hline $\mathrm{BOD}\left(\mathrm{mg} / \mathrm{dm}^{3}\right)$ & $1520 \pm 12.3$ & $435 \pm 11.8$ & 71.4 & $139 \pm 12.6$ & 68 & 25 \\
\hline Chloride $\left(\mathrm{mg} / \mathrm{dm}^{3}\right)$ & $750 \pm 15$ & $750 \pm 14.6$ & & $50 \pm 17.9$ & & 1000 \\
\hline $\mathrm{pH}$ & $7.28-7.31$ & $6.9-7.12$ & - & $7.16-7.2$ & - & $6.5-9$ \\
\hline Ammonia nitrogen $\left(\mathrm{mg} / \mathrm{dm}^{3}\right)$ & $490 \pm 28$ & $219 \pm 31.2$ & 55.3 & $129 \pm 19.9$ & 41 & 10 \\
\hline Ether extract (mg/dm3) & $1138 \pm 12$ & $220 \pm 9.6$ & 83.2 & $90 \pm 8.7$ & 60 & 50 \\
\hline TOC $\left(\mathrm{mg} / \mathrm{dm}^{3}\right)$ & $810 \pm 15$ & $136 \pm 11$ & 80.7 & $40.2 \pm 9.8$ & 70.4 & 30 \\
\hline The titre of coliform & $10^{-7}$ & $10^{-4}$ & - & $10^{-1}$ & - & - \\
\hline $\begin{array}{c}\text { Total number of mesophilic } \\
\text { bacteria }^{1}\end{array}$ & $25.6 \times 10^{5}$ & $8.81 \times 10^{5}$ & 65.6 & $0.31 \times 10^{5}$ & 96.4 & - \\
\hline $\begin{array}{c}\text { Total number of psychrophilic } \\
\text { bacteria }^{1}\end{array}$ & $49.4 \times 10^{5}$ & $14.4 \times 10^{5}$ & 70.8 & $0.42 \times 10^{5}$ & 97 & - \\
\hline
\end{tabular}

1) $1 \mathrm{~cm}^{3}$ of wastewater.

2) R-retention. 


\section{REFERENCES AND LEGAL ACT}

APHA AWWA WPCF. 1990. Standard Methods for the Examination of Water and Wastewater, $16^{\text {th }}$ ed. American Public Health Association, Washington, DC.

BARTKIEWICZ B. 2007.Oczyszczanie ścieków przemysłowych PWN, Warszawa.

BING LI., SUN YING-IAN., LIYU-YING. 2005. Pretreatment of coking wastewater using anaerobic sequencing batch reactor (ASBR), Journal of Zhejiang University, Science 6B,11: 1115-1123.

BOHDZIEWICZ J., SROKA E. 2006. Application of hybrid systems to the treatment of meat industry wastewater Desalination, 198, 1-3: 33-40.

CHÁVEZ P.C., CASTILLO L., R., DENDOOVEN, L. 2005. Poultry slaughter wastewater treatment with an up-flow anaerobic sludge blanket (UASB) reactor, Bioresource Technology 96 , 5: 1730-1736.

CHEONG D., HANSEN C.L. 2008.Effect of feeding strategy on the stability of anaerobic sequencing batch reactor responses to organic loading conditions, Bioresource Technology 99: 5058-5068.

DEL NERY V., DAMIANOVIC M.H.Z., BARROS, F.G. 2001.The use of upflow anaerobic sludge blanket reactors in the treatment of poultry slaughterhouse wastewater, Water Science Technology 44: 83-88.

GUDELIS-MATYS K. 2004. Oczyszczanie ścieków w zakładach mięsnych. Gospodarka Mięsna 09: 50-52.
KONIECZNY P. SZYMAŃSKI M. 2007. Ścieki przemysłu spożywczego-charakterystyka, zagrożenia, korzyści, Przegląd Komunalny 02: 88-100.

NARDI I.R., Del NERY V., AMORIM A.K.B., SANTOS N.G., CHIMENES F. 2011. Performances of SBR, chemical-DAF and UV disinfection for poultry slaughterhouse wastewater reclamation, Desalination 269: 184-189.

NECZAJ E., KACPRZAK M., KAMIZELA T., LACH J., OKONIEWSKA E. 2008. Sequencing batch reactor system for the co-treatment of landfill leachate and dairy wastewater, Desalination 222: 404-409.

Regulation of the Ministry of Environmental Protection, Natural Resources and Forestry dated 28 January 2009 on the classification of waters and conditions the sewage discharged to waters and soil should satisfy, (J. Law, No. 09.27, item 169).

SHAO X., PENG D.,TENG Z., XINGHUA J. 2008.Treatment of brewery wastewater using anaerobic sequencing batch reactor (ASBR), Bioresource Technology Vol. 99, Nr 8: 3182-3186.

YORDANOV D. 2010.Preliminary study of the efficiency of ultrafiltration treatment of poultry slaughterhouse wastewater, Bulgarian Journal of Agricultural Science 16 (No 6): 700-704. WÓJCIK-SZWEDZIŃSKA M., NOWAK D., STAŃCZYK-MAZANEK, E. 2000.Elementy biologii sanitarnej. Wydawnictwo Politechniki Częstochowskiej, tom 38. 